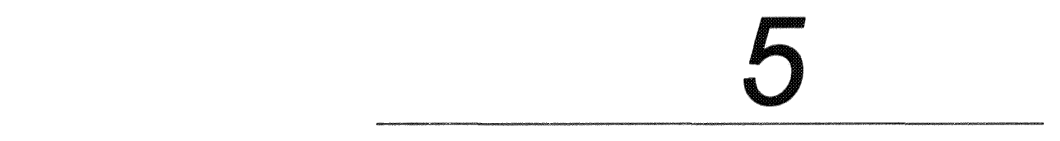

\title{
Urban Rainwater Composition Study
}

\author{
J. Alex McCorquodale, Donald Barbe, and Youchao Wang
}

Rainwater samples have been collected in New Orleans from October 1999 to October 2000. The samples were analyzed for water quality parameters: $\mathrm{pH}$, total Kjeldahl nitrogen $(\mathrm{TKN})$, nitrate $\left(\mathrm{NO}_{3}^{-}\right)$, ammonia $\left(\mathrm{NH}_{3}\right)$ and total phosphorus (TP). Average concentrations show clear seasonal variations with higher levels in spring and summer and lower levels in winter and fall for $\mathrm{NO}_{3}{ }_{3} \mathrm{~N}$ and TP. Comparison with Lake Pontchartrain parameters shows that the nitrogen concentration is significantly higher in rainwater than in the lake water but the TP is lower in rainwater than in the lake water. Comparison with agricultural areas (Washington Parish) shows that levels of major species of nutrients from urban areas (Orleans Parish) are higher than those of agricultural areas. The contrasts between urban and agricultural areas can be explained by proximity to the local pollution sources, such as motor vehicles, electric utilities, and petrochemical plants. The findings suggest that for some species of nutrients such as $\mathrm{NH}_{4}^{+}, \mathrm{NO}_{3}^{-}$and $\mathrm{PO}_{4}^{3-}$, anthropogenic emissions are major sources. A strong inverse relationship generally was found between the observed nutrient concentration and the quantity of rainfall in a particular event; however, the total loading due to rainfall increased with increased amounts of rainfall but at a diminishing rate. The rainfall concentrations of ammonia, nitrate/ nitrite and total phosphorus were converted to loads and compared to loads from urban storm runoff loads.

\section{I Introduction}

Atmospheric nutrient compounds cycle to the land and water through atmospheric deposition. Compared with surface water quality management, air pollution management involves special difficulties, including widespread point

McCorquodale, J., D.E. Barbe and Y. Wang. 2002. "Urban Rainwater Composition Study." Journal of Water Management Modeling R208-05. doi: 10.14796/JWMM.R208-05.

(C) CHI 2002 www.chijournal.org ISSN: 2292-6062 (Formerly in Best modeling practices for Urban Water Systems. ISBN: 0-9683681-6-6) 
and non-point sources, episodic pollution emissions, and long-range transport (Zhang et al., 1999). Nutrient deposition occurs as both wet and dry deposition. Wet deposition, predominantly in the rain and snow, carries nitrate, ammonia and phosphorous. Wet deposition accounts for most of the nitrogen removed from the atmosphere (Paerl et al., 1990). Dry deposition involves complex interactions between airborne nutrient compounds and plants, water, soil, rock, or roadway and building surfaces. One source of ammonia is the microbiological decay of animal and plant protein. Nitrate represents the most completely oxidized state of nitrogen commonly found in water. Atmospheric nutrients come from agriculture, fire, industry, soil, and lighting.

Whether nutrients enhance agricultural growth, cause ecological damage, or harm human health depends on its chemical form and the amount in the environment. Ammonia can be used directly by plants to produce protein. A certain amount of phosphate is essential for most plants and animals. But too much phosphate in water can contribute to eutrophication, especially when large amounts of nitrogen are also present. Similarly, in phosphorus-rich systems, the addition of available nitrogen can cause algal blooms as noted in Lake Pontchartrain (Ismail et al., 1998). The control of atmospheric deposition of pollutants requires the control of the anthropogenic sources that release those pollutants into the atmosphere.

The chemical composition of rainwater is known to be influenced by various meteorological factors such as wind-direction, rainfall rate, total amount of rainfall, and the height of the cloud base. To better understand the nutrient composition of precipitation in urban areas, rainwater samples (wet and wet-dry combined) were collected in New Orleans and analyzed for water quality parameters ( $\mathrm{pH}, \mathrm{TKN}, \mathrm{NO}_{3}^{-}, \mathrm{NH}_{3}$, and $\mathrm{TP}$ ).

The objectives of this chapter are to quantify the:

1. average concentration and monthly variation of nutrients in rainwater in the urban areas south of Lake Pontchartrain;

2. influence of dry fallout on rain composition;

3. differences in major nutrient composition between rainwater and Lake Pontchartrain;

4. differences in major rainwater components between urban areas south of Lake Pontchartrain and agricultural areas north of Lake Pontchartrain;

5. relationship between concentration and rainfall amount;

6. relationship between loads and rainfall amount; and

5. potential impact of atmospheric wet deposition on Lake Pontchartrain. 


\subsection{Background}

Greater New Orleans is located at longitude 900 04' and latitude $29057^{\prime}$ and has an area of approximately 128,000 acres $(51,840 \mathrm{ha}$.) with over one million residents. The urban area is surrounded by wetlands, which have national ecological significance and provide a vital buffer against storm surges from the Gulf of Mexico. Lake Pontchartrain is part of the Pontchartrain Estuary and is on the north side of the City while the Mississippi River passes through the urban area. Most of the storm water from the New Orleans area is pumped into Lake Pontchartrain. Figure 5.1 shows the urban area of this study.

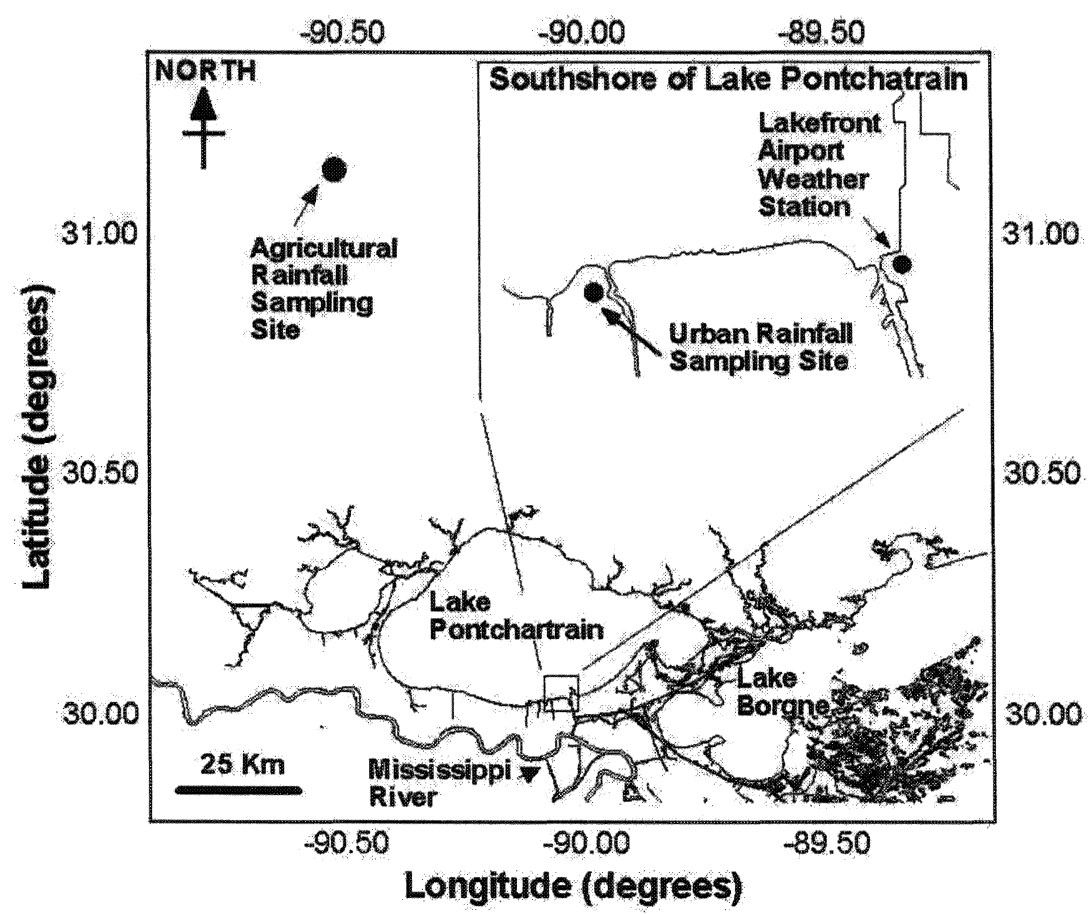

Figure 5.1 Map of the urban study area, showing the rainwater collection sites and weather station.

The climate of southeastern Louisiana is subtropical, influenced and moderated by many lakes, streams, and the Gulf of Mexico. During the hot, humid summers, prevailing southerly winds produce conditions favorable for afternoon thundershowers. The winters are mild and are dominated by frontal passages, producing squalls and sudden temperature drops. The average annual 
precipitation for the New Orleans area is 62 inches $(1570 \mathrm{~mm})$. Average wind speed recorded at the New Orleans International Airport is $9 \mathrm{mph}(4 \mathrm{~m} / \mathrm{s})$. Winds are predominantly from the south to southeast during the spring and summer, and north to northeast during the winter. The normal daily average temperature for October through March is $59.8^{\circ} \mathrm{F}\left(15.4^{\circ} \mathrm{C}\right)$, while for April through September it is $77.4^{\circ} \mathrm{F}\left(25.2^{\circ} \mathrm{C}\right)$. The temperature rises above $95^{\circ} \mathrm{F}$ $\left(35^{\circ} \mathrm{C}\right)$ on an average of only six days per year. The annual average humidity midday is $63 \%$ (Calhoun, 1998). A database of daily rainfall, temperature, and average daily wind speeds for the entire study period was compiled from Local Climatological Data [NOAA, National Climatic Data Center] (http:// www.nndc.noaa.gov/cgi-bin/nndc/buyOL-002.cgi). The National Climatic Data Center weather station is located at the New Orleans Lakefront Airport (Figure 5.1). The normal rainfall and actual rainfall are compared in Figure 5.2 during the study period.

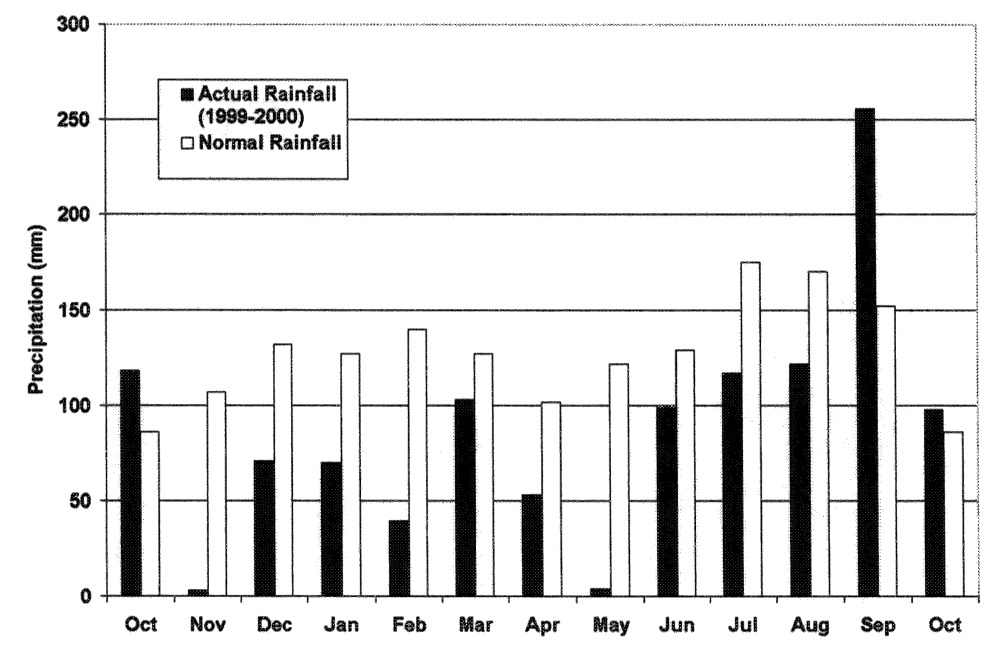

Figure 5.2 Monthly normal and observed rainfall amounts during the study period (1999-2000).

Rainwater is slightly acidic naturally, due to the dissolved carbon dioxide, nitrogen oxides, or sulfur dioxides that dissolve in it as it falls or, as it forms. The chemical investigation of precipitation is not a recent phenomenon. For over a century, researchers (Galloway, 1978) have been sampling precipitation to measure its chemical composition. But there has been very limited information on rainwater chemistry in this urban area. This study was undertaken to better understand the rainwater nutrient composition and the effects of the rainwater component on urban storm water quality and Lake Pontchartrain. 


\subsection{Methods and Equipment}

Samples were collected near the campus of the University of New Orleans (UNO), which is situated on the south shore of Lake Pontchartrain. The site was chosen so that sample bottles could be deployed and collected at short notice. As shown in Figure 5.3, the funnel-and-bottle sampler consisted of two compartments; one open compartment for the wet-dry sample and one compartment with a lid opened only during a rainfall event for the wet sample. Each sample was collected in a pre-cleaned glass funnel (diameter $200-\mathrm{mm}$ ) and a pre-cleaned glass bottle $(1000 \mathrm{ml})$. The rim of the funnel was $500 \mathrm{~mm}$ above the ground. The closed lid prevents dry deposition in this sample and the large diameter funnels permitted the collection of sufficient sample from light rainfall events while the high volume receiver ensured that major events were also collected satisfactorily. The funnel and the bottle of the sampler were washed with 1:1 hydrochloric acid solution and rinsed with double distilled water before use. A manual rain gauge was placed beside the equipment.

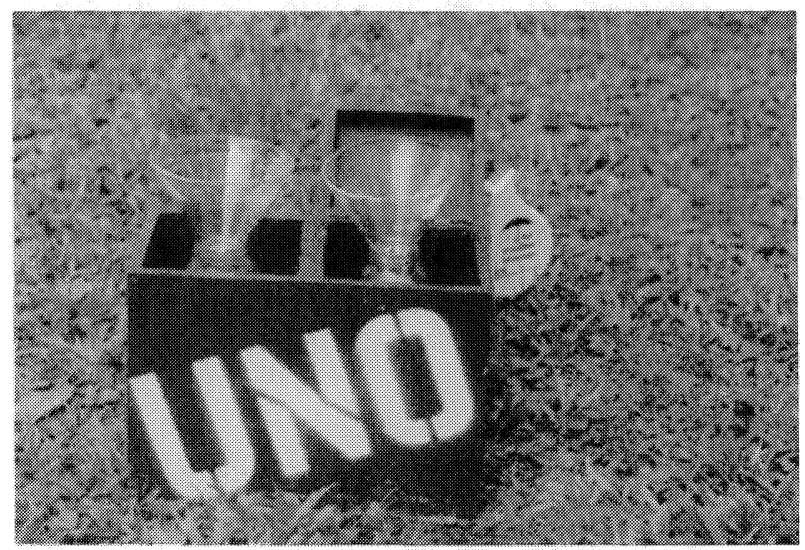

Figure 5.3 Rainwater sample collection apparatus.

After collection, the sample bottles were immediately transferred to the Environmental Engineering Laboratory at UNO for analysis. The outside of the bottle was cleaned and the bottle was taken into a clean room, where the sample was analyzed immediately. Analyses of rainwater samples collected at the rainfall station included:

- $\mathrm{pH}$

- Dissolved nitrate plus nitrite as nitrogen (nitrate),

- Dissolved ammonia plus ammonium as nitrogen (ammonia),

- Total phosphorus,

- Total Kjeldahl nitrogen (ammonia plus organic nitrogen). 
The analytical methods used for these constituents were based on Standard Methods for Examination of Water and Wastewater (APHA et al., 1998). The $\mathrm{pH}$ of the rainwater sample was determined using a Hach $\mathrm{pH}$ meter; the meter was calibrated using buffers $(\mathrm{pH}=4.00$ and $\mathrm{pH}=7.00)$. The $\mathrm{NH}_{3}{ }^{-} \mathrm{N}$ was analyzed using the U.S. Environmental Protection Agency (EPA) approved Nessler Method. The $\mathrm{NO}_{3}{ }_{3}^{-} \mathrm{N}$ was analyzed using the Cadmium Reduction Method. The TKN, also referred to as crude protein, was used to determine ammonia plus organic nitrogen present in the sample. A preliminary digestion was used to oxidize carbon compounds to carbon dioxide and to convert forms of nitrogen present (amino acid, proteins, peptides) to ammonia. The TKN was determined using the automated colorimetric techniques after digestion. The TP was obtained using the Acid Persulfate Digestion Method. The dry deposition can be calculated by using the difference between bulk and wet concentration and rainfall amount. Rainwater nutrient component data at Washington Parish located at north of Lake Pontchartrain (Latitude $30048^{\prime} 41^{\prime \prime}$, Longitude $90010^{\prime}$ $51 ")$ were obtained from NADP/NTN Sites in Louisiana (http://nadp.sws.uiuc.edu).

\subsection{Results}

The individual concentration of rain samples was highly variable, depending on the sample location and time. For example, the concentration of TP ranges from $0.01 \mathrm{mg} / \mathrm{L}$ to $1.98 \mathrm{mg} / \mathrm{L}$, and the mean concentration is $0.23 \mathrm{mg} / \mathrm{L}$ during the study period. Monthly wet weighted mean concentrations in urban areas are calculated and given in Table 5.1. As shown in Table 5.1, monthly mean concentrations show a clear seasonal variation with higher levels in the spring and summer and lower levels in the winter and fall for most of the nutrients. The nutrient concentrations for bulk and wet-only samples were compared. The findings showed that dry deposition collected using bulk sampling, collecting precipitation and dry fallout in the same container, had phosphorus much higher than in the wet-only samples; while nitrogen concentrations as ammonia and nitrite and nitrate were only slightly higher in the bulk samples than in the wetonly samples (Figure 5.4).

The individual rainfall results show that higher concentrations are generally associated with smaller rainfall events. In order to clearly understand the relationship between concentration and rainfall amount, four class intervals of precipitation events were used for the events sampled (Figure 5.5). An inverse relationship generally was found between the observed nutrient concentration and the quantity of rainfall in a particular event. The $\mathrm{pH}$ show more acidity with 
Table 5.1 Monthly wet precipitation weighted mean concentration and ranges (September 1999 - November 2000).

\begin{tabular}{lccccc}
\hline Month & $\mathrm{pH}$ & $\begin{array}{c}\mathrm{T}-\mathrm{P} \\
(\mathrm{mg} / \mathrm{l})\end{array}$ & $\begin{array}{c}\mathrm{NH}_{3}-\mathrm{N} \\
(\mathrm{mg} / \mathrm{l})\end{array}$ & $\begin{array}{c}\mathrm{NO}_{3}-\mathrm{N} \\
(\mathrm{mg} / \mathrm{l})\end{array}$ & $\begin{array}{c}\mathrm{TKN} \\
(\mathrm{mg} / \mathrm{l})\end{array}$ \\
\hline October & 5.78 & 0.13 & 0.13 & 0.16 & 0.60 \\
November & 6.10 & 0.38 & 0.23 & 0.28 & 0.50 \\
December & 6.42 & 0.10 & 0.14 & 0.17 & 0.75 \\
January & 5.34 & 0.19 & 0.15 & 0.18 & 0.81 \\
February & 6.40 & 0.09 & 0.12 & 0.14 & 0.65 \\
March & 5.55 & 0.14 & 0.15 & 0.17 & 0.87 \\
April & 5.83 & 0.40 & 0.70 & 0.26 & 1.48 \\
May & 6.30 & 0.27 & 0.63 & 0.39 & 1.32 \\
June & 5.39 & 0.21 & 0.30 & 0.32 & 0.60 \\
July & 5.18 & 0.21 & 0.36 & 0.32 & 0.60 \\
August & 4.94 & 0.15 & 0.25 & 0.40 & 0.61 \\
September & 4.81 & 0.16 & 0.26 & 0.14 & 0.38 \\
October & 5.42 & 0.11 & 0.17 & 0.12 & 0.34 \\
Maximum & 6.42 & 0.40 & 0.70 & 0.40 & 1.48 \\
Minimum & 4.81 & 0.09 & 0.09 & 0.11 & 0.34 \\
\hline
\end{tabular}

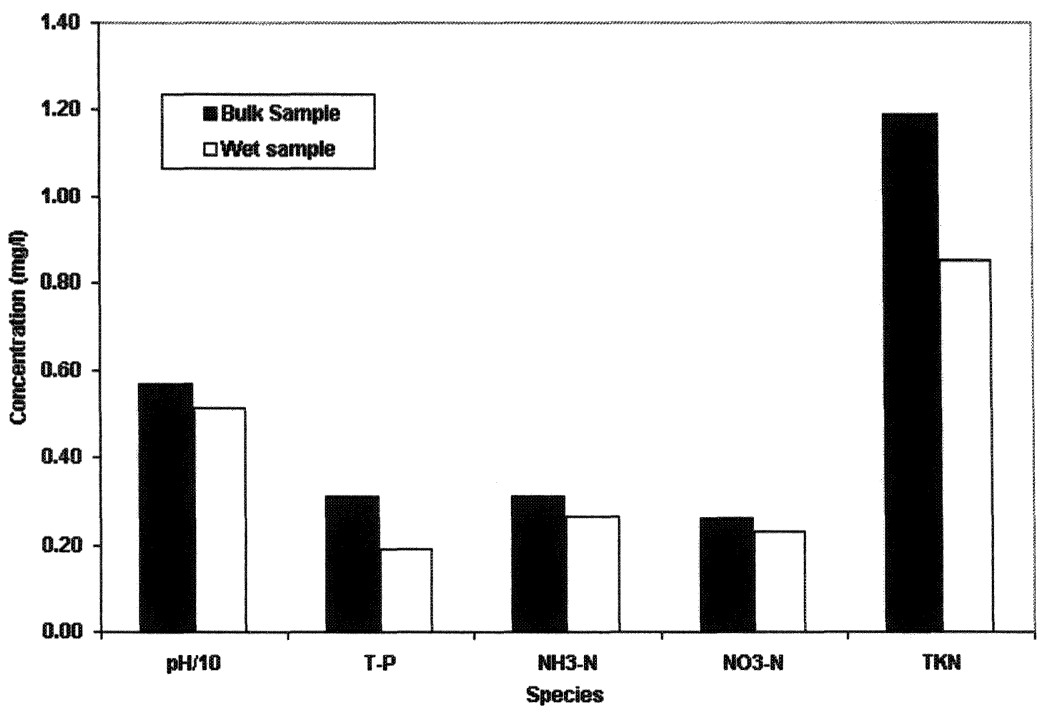

Figure 5.4 Annual average concentrations for wet and bulk samples.

increasing rainfall amount probably because the buffering agents such as calcium are washed out of the atmosphere to a great extent, thereby producing more acidity. 


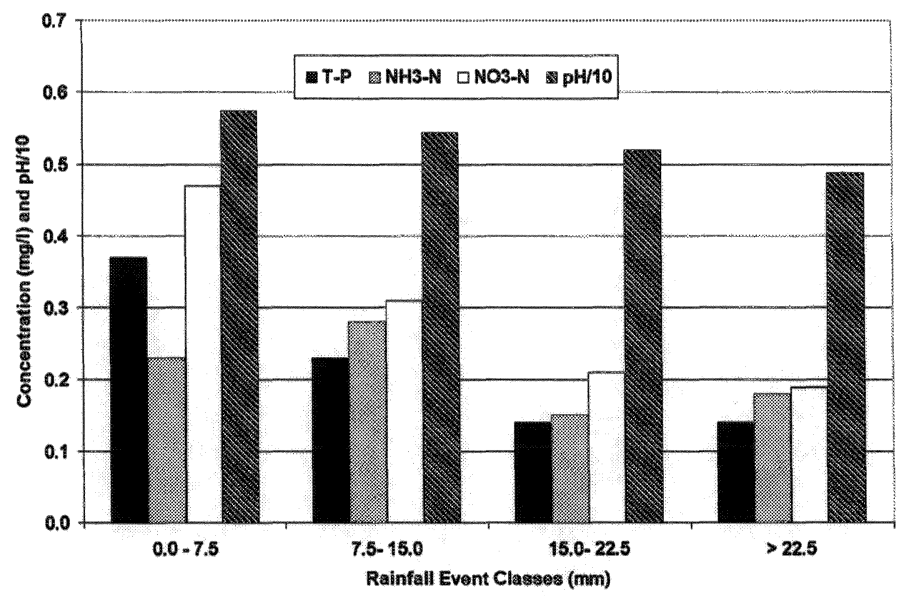

Figure 5.5 Average concentrations in urban areas for different rainfall events.

For closely spaced consecutive rain events in November 16-18, 2000, the concentration of a series of individual event was compared to each other. The results show that for the consecutive events, the concentration decreases (Figure 5.6). In a successive rainfall event, the results show that the rate of nutrient build up is less than that of nutrient washoff, so the concentration decreases with the succeeding rainfall events. The relationship between nutrient load and rainfall amount for different rainfall event classes are shown in Figure 5.7. The nutrient deposition load per event tended to increase with increasing amounts of rain but at a diminishing rate.

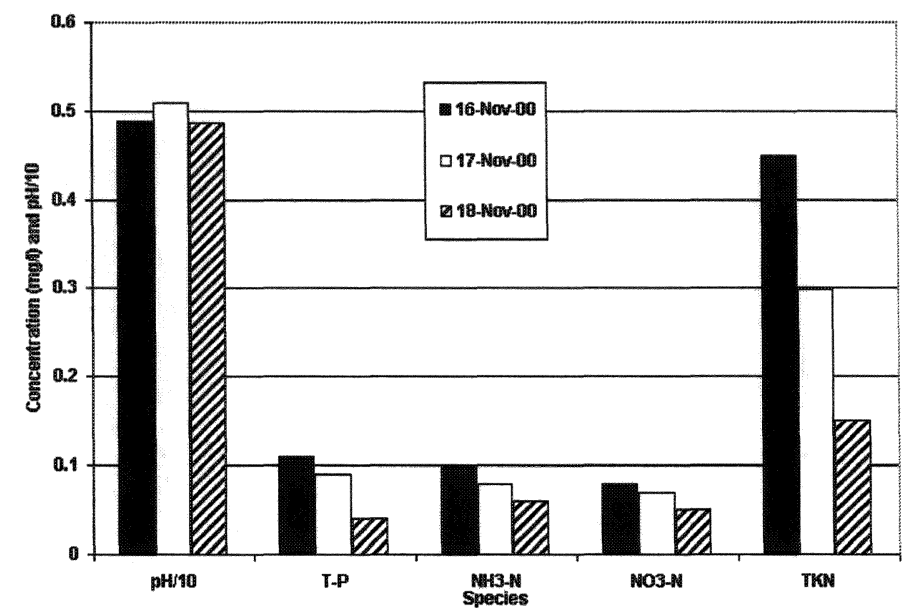

Figure 5.6 Concentrations of three consecutive rain events in urban area. 


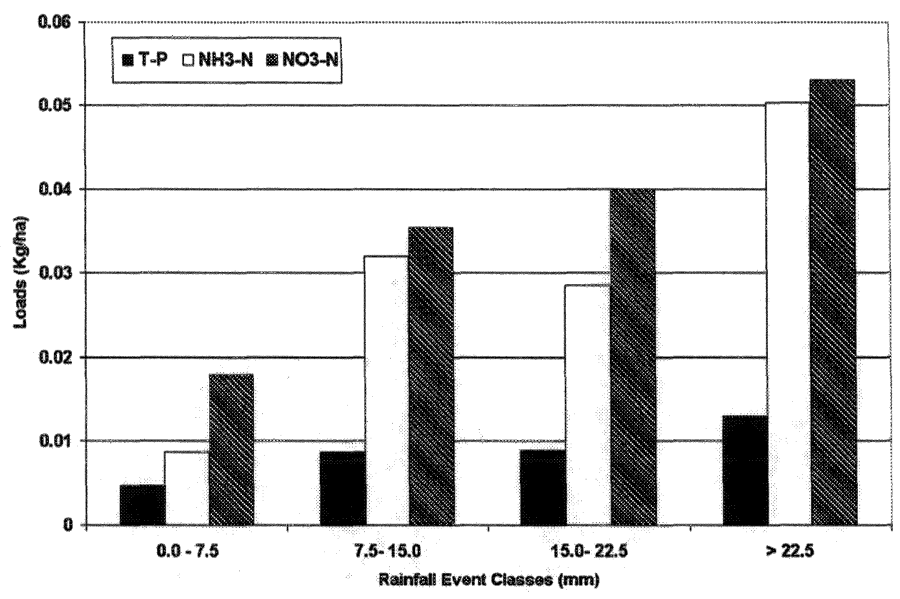

Figure 5.7 Average loads in the urban area for different rainfall event classes.

\subsection{Discussion}

The results show a seasonal variation of rainwater nutrient concentrations. The climate mechanisms of the central Gulf coast of the U.S. have been extensively studied (Cruise and Arora, 1990; Faiers et al, 1994). These studies have revealed that the climate of the area is dominated by two mechanisms: frontal activity in the winter and early spring (October-April); and convective activity during the summer and fall months. In summer, southeast winds blow over the land to Lake Pontchartrain, which carries more industrial pollution as well as emissions from traffic. In summer, lightning converts large amounts of atmospheric nitrogen $\left(\mathrm{N}_{2}\right)$ directly to nitrates. The effects of wind and lightning may cause the nutrient concentrations to be higher in the summer than the winter. It is possible that the wetlands may contribute some ammonia.

Monthly loads from the precipitation in the New Orleans urban area are shown in Figure 5.8. A drought persisted for part of the sampling period with an annual rainfall of only 44 inches $(1118 \mathrm{~mm})$ compared to the normal of 62 inches $(1570 \mathrm{~mm})$. Due to the drought, the loads in November 1999 and May 2000 were very low and therefore probably not representative of a normal year.

A comparison with the concentration of Lake Pontchartrain water (Carnelos, 2000) during the study period shows that the nitrogen concentration is higher in rainwater than in the lake water but the total phosphorus is lower in rainwater than in the lake water (Figures 5.9 and 5.10). The results suggest that the nitrogen in the lake is consumed quickly due to algae and biological conversion. 


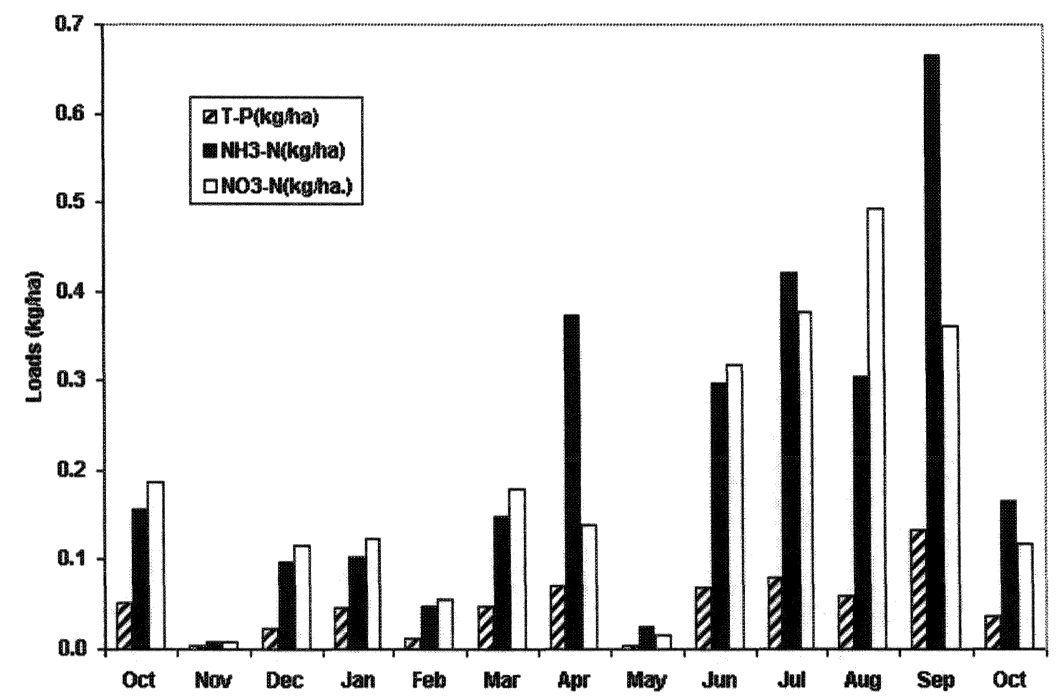

Figure 5.8 Monthly loads due to the rainwater in the urban area.

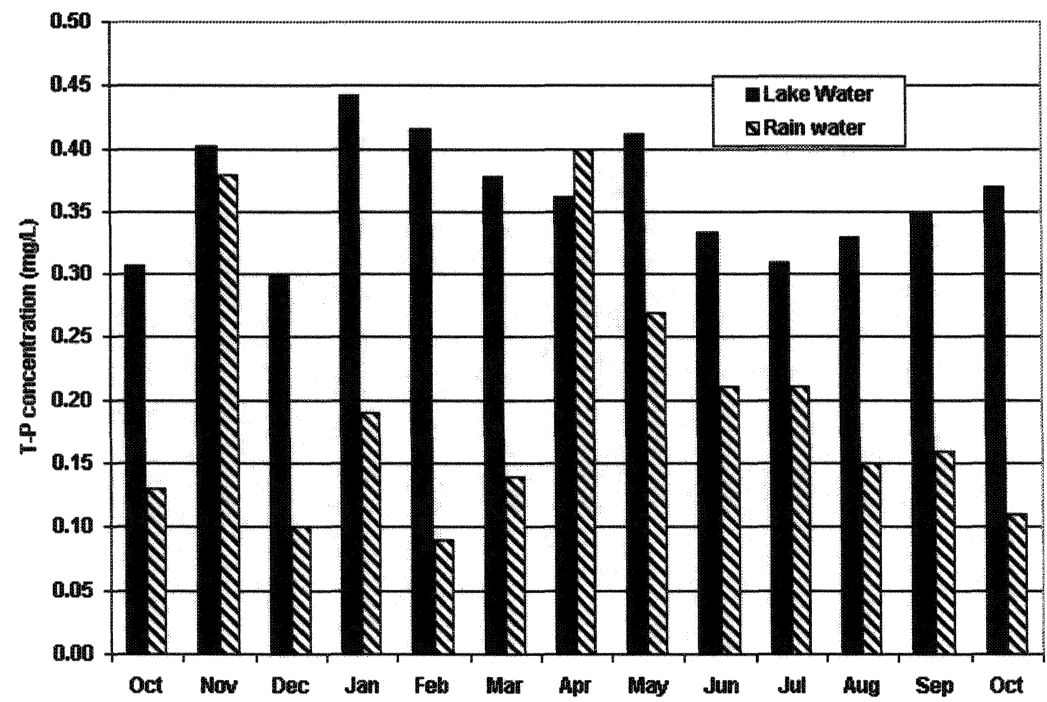

Figure 5.9 Comparison of T-P concentration between Lake Pontchartrain and rain samples.

The nitrogen concentration data for rainfall in agricultural areas in Washington Parish (http://nadp.sws.uiuc.edu) were obtained $\left(\mathrm{NH}_{3}-\mathrm{N}\right.$ and $\mathrm{NO}_{3}-\mathrm{N}$ ). The concentrations for urban and agricultural areas were compared for the study period and it was found that levels of major species of nutrients 


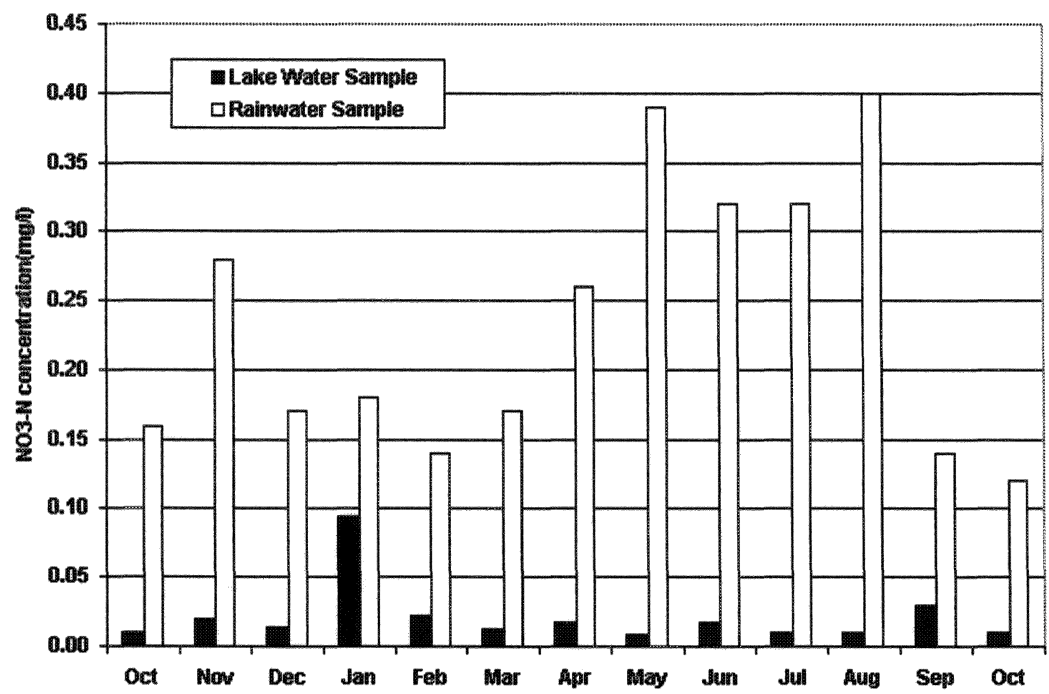

Figure 5.10 Comparison of $\mathrm{NO}_{3}-\mathrm{N}$ concentrations between Lake Pontchartrain and rain samples.

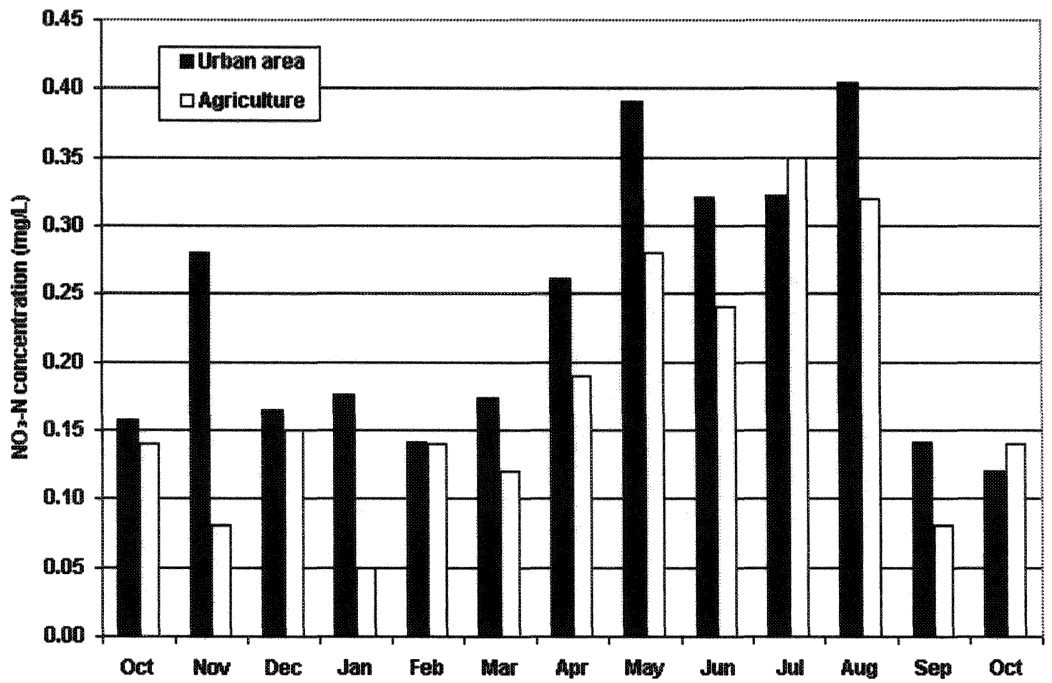

Figure 5.11 Comparison of $\mathrm{NO}_{3}-\mathrm{N}$ values between urban and agricultural areas.

from urban areas were higher than those of agricultural areas (Figures 5.11 and 5.12). The comparison of rainwater chemistry with other cities shows that the ammonia and nitrate concentrations in New Orleans are similar to Houston, but less than New York and greater than Miami and Tampa (Table 5.2). 


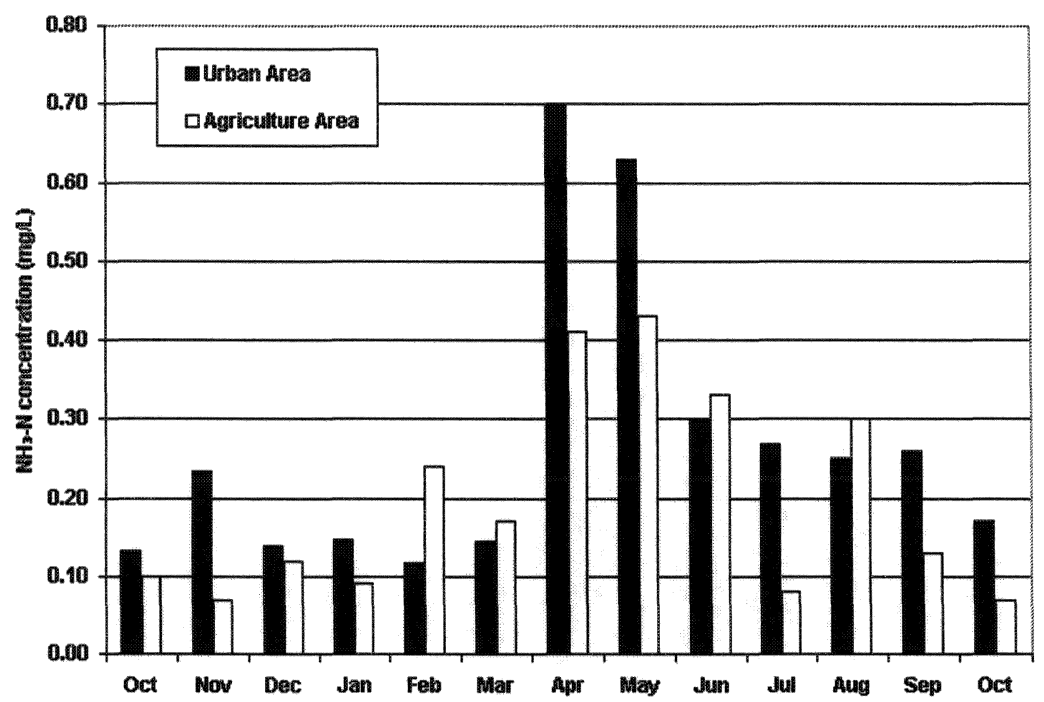

Figure 5.12 Comparison of $\mathrm{NH}_{3}{ }^{-} \mathrm{N}$ values between urban and agricultural areas.

Table 5.2 Comparison of chemical species in rainwater with other cities (data from NADP).

\begin{tabular}{lll}
\hline & $\mathrm{NH}_{4}-\mathrm{N}(\mathrm{mg} / \mathrm{L})$ & $\mathrm{NO}_{3}-\mathrm{N}(\mathrm{mg} / \mathrm{L})$ \\
\hline Miami, FL & 0.09 & 0.1 \\
Tampa, FL & 0.12 & 0.18 \\
Houston, TX & 0.25 & 0.23 \\
New York, NY & 0.21 & 0.37 \\
New Orleans, LA & 0.20 & 0.23 \\
\hline
\end{tabular}

If we assume that the rainwater composition over Lake Pontchartrain is represented by the average of the urban and agricultural atmospheric wet deposition, using the total area of Lake Pontchartrain $\left(1630 \mathrm{~km}^{2}\right)$ and an annual rainfall of 62 inches $(1580 \mathrm{~mm})$ gives the atmospheric input of total dissolved inorganic nitrogen $\left(D \mathbb{N}=\mathrm{NO}_{3}^{-}+\mathrm{NO}_{2}^{-}+\mathrm{NH}_{3}\right)$ and phosphorus to Lake Pontchartrain as approximately $1.6 \times 106 \mathrm{~kg} / \mathrm{yr}$ and $2.8 \times 105 \mathrm{~kg} / \mathrm{yr}$, respectively. Compared to the nutrient loads obtained from the National Pollution Discharge Elimination System (NPDES) of $4 \times 105 \mathrm{~kg} / \mathrm{yr}$ and $3 \times 105 \mathrm{~kg} / \mathrm{yr}$ for storm runoff loads of DIN and TP from Greater New Orleans, the nutrient loads from the direct wet fall are significant in the Lake Pontchartrain System (Haralampides, 2000).

The contrasts between urban and agricultural areas can be explained by proximity to the local pollution sources, such as motor vehicles, electric utilities, petrochemical plants and possible ammonia contribution from wetlands located 
south of the urban areas. The ambient air quality data from the National Air Monitoring Station shows that the ground level ambient air concentrations of $\mathrm{NO}$ and $\mathrm{NO}_{2}$ in New Orleans are two to four times higher than in the agricultural area (www.deq.state.la.us). This is consistent with other results, for example, the atmospheric nitrogen deposition to New York City's forests were two to three times greater than in the suburban and rural forests along the transect (http://www.louisville.edu). The wet inorganic nitrogen deposition rate ranges from $1 \mathrm{~kg} / \mathrm{ha}$ to more than $7 \mathrm{~kg} / \mathrm{ha}$ through out the United States. Parts of eight states from eastern Nebraska to western Ohio received $7 \mathrm{~kg} / \mathrm{ha}$ or higher (http://nadp.sws.uiuc.edu). This compares to $3 \mathrm{~kg} / \mathrm{ha}$ for the urban area of New Orleans and $2.1 \mathrm{~kg} /$ ha for the agricultural area north of Lake Pontchartrain.

\subsection{Conclusion}

- Dry fall represent $12 \%$ of the total nitrate; $14 \%$ of the total ammonia; $37 \%$ of the total phosphorus; and $27 \%$ of the total Kjeldahal nitrogen.

- The nitrogen concentrations are significantly higher in rainwater than in the Lake Pontchartrain water but the total phosphorus concentrations are lower in rainwater than in the Lake Pontchartrain water.

- The concentrations of major nutrients from urban areas are higher than those of an agricultural area north of Lake Pontchartrain. The findings suggest that for some nutrient species such as $\mathrm{NH}_{3}, \mathrm{NO}_{3}^{-}$and $\mathrm{TP}$, anthropogenic emissions are major sources.

- A strong inverse relationship generally was found between the observed nutrient concentration and the quantity of rainfall in a particular event; however, the total loading due to rainfall increased with increase amounts of rain but at a diminishing rate.

- The loads from the wet deposition to the Lake Pontchartrain are significant compared to loading from urban storm water runoff.

\section{References}

American Public Health Association, American Water Works Association, and the Water Environment Federation, 1998, Stand Methods for the Examination of Water and Wastewater, 20th Edition.

Calhoun, M., Louisiana Almanac, 1997-1998 edition. 
Carnelos, S., 2000, Urban Runoff Drainage to Lake Pontchartrain: Outfall Plume Modeling and Shoreline Water Quality Study, Master's Thesis, Department of Civil and Environmental Engineering, University of New Orleans, New Orleans, LA70148.

Faiers, G. E., B. D. Keim, and K.K. Hirschboeck, 1994, A Synoptic Elevation of Frequencies and Intensities of Extreme Three and 24-Hour Rainfall in Louisiana. Professional Geographer, Vol. 46, No.2 pp. 156-163.

Galloway J.N., 1978, The collection of precipitation for chemical analysis. Tellus, Vol. 30, pp. 71-82.

Georgii, H.W., Perseke, C., and Rohbock, E., 1984, Deposition of acidic components and heavy metals in the federal Republic of Germany for the period 1979-1981. Atmospheric Environment, Vol. 18, pp. 581-589.

Haralampides, Katy, 2000, Study of the Hydrodynamics and Salinity Regimes of the Lake Pontchartrain, A Dissertation for Doctor of Philosophy in Engineering and Applied Science, Department of Civil and Environmental Engineering, University of New Orleans, New Orleans, LA 70148.

http:// nadp.sws.uiuc.edu

http://www.nndc.noaa.gov/cgi-bin/nndc/buyOL-002.cgi

http://www.dep.state.la.us

http://www.louisville.edu

Ismail, I., Cothern, G., Hannoura, A. and McCorquodale, J.A., 1998, "Lake Pontchartrain Water Quality and Algal Bloom Assessment," Proceedings WEF 98 Conference in Orlando, FL, USA, Oct.

Paerl, H.W., J. Rudek, and M.A. Mallin, 1990, Stimulation of phytoplankton production in coastal waters by natural rainfall inputs: nutritional and trophic implications, Marine Biol., Vol. 107, pp 247-254.

Zhang, J., Chen, S.Z., Yu, Z.G., Wang, C.S., and Wu, Q.M., 1999,Factors influencing changes in rainwater composition from urban versus remote regions of the Yellow Sea, J. Geophys. Res., Vol. 104, No., D1, 1631-1644. 